Social Work \& Education

๑) SW\&E, 2019

УДК 378.04:316.61

DOI: $10.25128 / 2520-6230.19 .1 .7$

Агаркова, Н. (2019). Підготовка майбутніх вихователів та вчителів початкових класів до роботи 3 дітьми з особливими освітніми потребами, Social Work and Education, Vol. 6, No. 1., pp. 70-79. DOI:10.25128/2520-6230.19.1.7

$\begin{array}{cc}{ }^{\odot s w \& E, ~} 2019 & \text { ПІДГОТОВКА МАЙБУТНІХ } \\ & \text { ВИХОВАТЕЛІВ ТА ВЧИТЕЛІВ } \\ \text { УДК } 378.04: 316.61 & \text { ПОЧАТКОВИХ КЛАСІВ ДО } \\ \text { DOI: } 10.25128 / 2520-6230.19 .1 .7 & \text { РОБОТИ } 3 \text { ДІТЬМИ } 3 \\ & \text { ОСОБЛИВИМИ ОСВІТНІМИ } \\ & \text { ПОТРЕБАМИ }\end{array}$

Наталія Агаркова, кандидат педагогічних наук, доиент кафедри початкової, дошкільної та професійної освіти Харківського національного педагогічного університету імені Г. С. Сковороди м. Харків, Украӥна haschipsyt85@gmail.com

ORCID: 0000-0002-9885-4092

Article history:
Received: January 07, 2018
1st Revision: Febuary 21, 201
Accepted: March 30, 2019

Article history:
Received: January 07, 2018
1st Revision: Febuary 21, 2018
Accepted: March 30, 2019

Article history:
Received: January 07, 2018
1st Revision: Febuary 21, 2019
Accepted: March 30, 2019

Article history:
Received: January 07, 2018
1st Revision: Febuary 21, 201
Accepted: March 30, 2019

АНОТАЦІЯ. Підготовка майбутнього вихователя та вчителя початкової школи до роботи 3 дітьми 3 особливими освітніми потребами стає пріоритетним завданням держави, та суспільства зокрема. Інклюзивна освіта дозволяє включати таких дітей у дитячі садки та шкільну систему освіти, забезпечувати їх повноцінну соціалізацію. Проаналізовано психолого-педагогічну літературу, нормативноправове забезпечення професійної підготовки студентів до навчання i виховання дітей 3 особливими освітніми потребами. Належна увага приділяється компонентам системи підготовки майбутніх вихователів та вчителів початкових класів до роботи 3 дітьми 3 особливими освітніми потребами 3 метою підвищення рівня їх готовності до роботи із дітьми $з$ особливими освітніми потребами.

Ключові слова: інклюзивна освіта; діти 3 особливими освітніми потребами; підготовка майбутнього вчителя; початкова освіта; підготовка майбутнього вихователя; дошкільна освіта. 


\section{Вступ}

В останні роки на Україні простежуються негативні тенденції відповідно до стану здоров'я всіх вікових груп населення країни. На початок 2018 р. на Україні було зареєстровано 2,636 млн. людей $(6,1 \%$ від загальної кількості населення) зі статусом інваліда, 3 них 159 тис. - діти (Черенько, 2006). Згідно статистики, на початок 2018 р. на 1000 осіб припадало 62 людини з інвалідністю. У 2011 р. ця цифра становила 59 осіб, у 2014 р. - 63 («Населення та міграція, 1998-2019»). Кількість груп дітей 3 інвалідністю у дитячих садках та школах 3 урахуванням особливих потреб 3 кожним роком збільшується. За прогнозами науковців (Яковлева \& Баранов, 2009), у зв'язку з погіршенням екології, кількість дітей $з$ обмеженими можливостями здоров'я, нажаль, буде зростати.

Однак, процес входження нашої країни до світової економічної спільноти зумовили зміни ставлення суспільства до проблем таких людей.За останні роки (2014-2019 pp.) прийнято низку законів, спрямованих на інтеграцію їх в освітній процес.Право дітей 3 особливими освітніми потребами на рівний доступ до якісної освітизакріплене Конституцією України; визначене законами України «Про освіту», «Про охорону дитинства», Про основи соціальної захищеності інвалідів в Україні», «Про реабілітацію інвалідів в Україні»та міжнародними документами 3 питань прав інвалідів. Відповідно до закону України «Про внесення змін до законодавчих актів з питань загальної середньої та дошкільної освіти щодо організації навчально-виховного процесу» 32010 p. у закладах дошкільної освіти та загальноосвітніх навчальних закладах запроваджується інклюзивне навчання.Широке впровадження ідей інтеграції та інклюзії у дитячі садки та загальноосвітні школи України значною мірою залежить від кваліфікації кадрів, що вимагає внесення змін у процес підготовки майбутніх вчителів. Сучасне суспільство висуває до випускника, майбутнього вчителя, якому доведеться працювати 3 дітьми особливими освітніми потребами,специфічні вимоги.

\section{Аналіз останніх досліджень і публікацій}

Проблеми навчання дітей 3 особливими освітніми потребами та їх інтеграцію в освітне середовище загальноосвітніх навчальних закладів досліджували В. Бондар, В. Ляшенко, А. Савченко. Вчені переконані, що інклюзивна освіта для дітей з порушеннями розвитку за всіма параметрами має бути такою ж, як освіта, яку отримують діти без порушень. Вивчення розвитку системи спеціальних навчальних закладів, методик ранньої діагностики психічного розвитку дітей представлено в роботах Л. Виготського, А. Венгера, А. Запорожця, Г. Костюка. У своїх працях вчені обгрунтовують принципові положення про особливості розвитку психічних процесів у дітей різного віку та різних категорій, механізми формування соціальної та комунікативної активності у дітей з різними психофізичними порушеннями.

На даний час вченими ведуться дослідження в галузі підготовки педагогічних кадрів для роботи в умовах інклюзивної освіти. Зокрема, питання професійної підготовки педагогів розглядали В. Гриньова, М. Євтух, І. Зязюн, В. Лозова та інші. А. Колупаєва, В. Синьов, В. Бондарь, А. Шевцов, В. Зарецький та інші розглядають питання готовності професійної діяльності педагогів в роботі 3 дітьми 3 особливими можливостями здоров'я. Незаперечним є той факт, що багатогранною та багатоаспектною є проблема підготовки педагогів до роботи 3 дітьми, які мають особливі освітні потреби. Зарубіжні науковці (Ph. Jones, E.H. Mattson, D. Rodrigues) вивчаючи питання підготовки педагогів до організації інклюзивного навчання зазначають, що основним компонентом підготовки 
педагогів є обмін досвідом з колегами. Наприклад, D. Rodrigues розглядає модель постійного навчання педагогів, що сприяє удосконаленню їх професійних навичок в інклюзивній практиці. Впровадження інклюзивного навчання у вітчизняний науковий простір вивчали такі науковці, як А. Колупаєва, 3. Мовкебаїва, О. Рассказова, А. Шивцов, В. Шишенко, формування інклюзивної компетентності вчителів та вихователів дошкільних закладів - С. Альохіна, Ю. Бойчук, О. Бородіна та інші. 3. Мовкебаїва в своїх дослідженнях зазначає про необхідність підготовки програмного змісту у відповідності зі специфічними особливостями та наявними можливостями кожної дитини 3 порушеним розвитком; побудови продуктивної міжособистісної взаємодії із здоровими учнями; створення дидактичних матеріалів, що забезпечують успішне навчання та розвиток учнів з особливими освітніми потребами.

Теоретичний аналіз психолого-педагогічної та соціальної літератури 3 проблеми дослідження засвідчив значимість впровадження інклюзії в загальноосвітній простір та показав факт підвищеної уваги вчених до пошуку шляхів оптимізації цього процесу.

Оскільки традиційної загальнопедагогічної підготовки фахівців для ефективної роботи 3 дітьми 3 особливими освітніми потребами недостатньо, у більшості педагогів відсутня мотивація до роботи 3 даною категорією дітей, $\epsilon$ страх, бажання уникнути такої роботи. Підтвердженням вище сказаного $\epsilon$ результати проведеного нами анкетування вихователів дошкільних закладів та вчителів початкових класів м. Харкова (Україна). За даними досліджень, 67 \% вихователів не володіють методами роботи 3 дітьми 3 особливими освітніми потребами, $24 \%$ вчителів початкових класів не знайомі зі спеціальними програмами, не знають психологічних особливостей дітей зазначеної категорій, не мають досвіду роботи у команді. Це в свою чергу призводить до неоднозначного ставлення 3 боку батьків i педагогів до втілення ідеї інклюзивного навчання. Так за підтримку інтегрованого навчання виступили майже $91 \%$ батьків, та тільки 59 \% вихователів закладів дошкільної освітий $73 \%$ вчителя початкових класів. Отримані результати свідчать, що батьківський колектив є домінантним по відношенню до педагогічного та визнає інклюзивне навчання як потребу, у той же час педагогічна громадськість визначає ії як необхідність.Зазначимо, що інклюзивна освіта спрямована не на ліквідацію сформованої системи спеціальної (корекційної) освіти, а на з'єднання, взаємопроникнення та взаємовідповідальність слабо пов'язаних між собою систем загальної та спеціальної освіти. 3 огляду на те, що батьки дитини 3 особливими освітніми потребами мають можливість вільного вибору закладу освіти, то кожному педагогу необхідно мати певний рівень сформованості інклюзивної компетентності як складової його професіоналізму. Педагогічні працівники закладів освіти зобов'язані знати основи корекційної педагогіки та спеціальної психології, мати уявлення про особливості психофізичного розвитку дітей, про методики навчання та технології організації освітнього та реабілітаційного процесу. Разом з тим, виникає ряд протиріч між зростаючою інтеграцією дітей 3 особливими освітніми потребами в установи освіти та відсутністю спеціально підготовлених педагогів до роботи 3 такими дітьми в загальноосвітніх закладах освіти; між потребою освітньої практики у кваліфікованих фахівцях, які володіють високим рівнем сформованості інклюзивної компетентності, та традиційним змістом професійної підготовки вихователів та майбутніх вчителів початкової школи. В цьому ракурсі особливого значення набуває проблема підготовки майбутніх вихователів дошкільних закладів освіти та майбутніх вчителів початкової школи до роботи 3 дітьми з особливими освітніми потребами. 
Мета статті - визначити сутність та особливості підготовки майбутніх вихователів та вчителів початкових класів до роботи 3 дітьми 3 особливими освітніми потребами.

Методологія дослідження. Методологічною основою дослідження $\epsilon$ врахування вікових особливостей (Л. Виготський, Д. Ельконін), фундаментальні положення про закони розвитку дитини 3 особливостями розвитку (Л. Виготський, С. Рубінштейн), базові потреби молодших школярів (В. Сухомлинський, Ш. Амонашвілі), діяльнісний підхід до вивчення особистості (Л. Виготський, А. Леонтьєв, П. Гальперін, Д. Ельконін, В. Давидов, А. Петровський), концептуальні положення про специфіку процесу навчання дітей 3 особливостями розвитку (Б. Ананьєв, П. Гальперін, Н. Тализіна). Акмеологічний підхід як методологічна основа інклюзії розкриває досягнення кожним учнем інклюзивного освітнього процесу розвитку свого особистісного потенціалу, досягнення своєї вершини розвитку, самоактуалізації. Суттєву роль в методології мають базові принципи, які $\epsilon$ сполучними елементами між закономірностями та практикою. Так, інклюзивне навчання грунтується на таких принципах, як: 1) принцип системності, тобто інклюзивне навчання є системним явищем в освіті, що охоплює всю систему освіти України; 2) принцип доступності, тобто інклюзивне навчання має місце на всіх рівнях освіти, хоча й вимагає створення спеціальних умов в кожній освітній установі для будь-якої категорії учнів 3 числа осіб 3 особливостями психофізичного розвитку; 3) комплексність впливу фахівців; 4) принцип врахування індивідуальних освітніх потреб кожного учня 3 особливостями психофізичного розвитку; 5) принцип толерантності, тобто формування поважливих відносин всередині колективу, тобто повага до особливостей і їх прийняття. Методами дослідження $є$ вивчення соціологічної, психолого-педагогічної та навчально-методичної літератури, порівняльно - зіставний аналіз підходів до навчання дітей 3 особливими освітніми потребами, вивчення та узагальнення досвіду в сфері інклюзивної освіти на Україні; емпіричні: вивчення навчально-програмної документації з організації навчання дітей 3 особливими освітніми потребами в масових школах, соціологічні: опитування, анкетування, інтерв'ювання (вчителів, батьків, учнів, управлінців); діагностичні: аналіз успішності, аналіз сформованості компонентів пізнавальної діяльності тощо. Значення інклюзивної освіти для розвитку сучасного суспільства вельми вагоме, воно дає надію на те, що діти 3 особливими освітніми потребами отримують право на повноцінну освіту й зможуть реалізувати свій потенціал та знайти своє місце у житті.

\section{Основна частина}

Закон України «Про освіту» визначив поняття дитини 3 особливими освітніми потребами, як «особа, яка потребує додаткової постійної чи тимчасової підтримки в освітньому процесі 3 метою забезпечення іiі права на освіту». Інклюзивне навчання - це система освітніх послуг, гарантованих державою, що базується на принципах недискримінації, врахування багатоманітності людини, ефективного залучення та включення до освітнього процесу всіх його учасників (Закон України «Про освіту», 2017). Тобто сюди можуть бути віднесені особи, які здобувають спеціалізовану освіту або можуть екстерном опановувати зміст навчальних предметів, учні з інвалідністю, діти-біженці.

Проведений аналіз наукової літератури дозволив зробити висновок, що в умовах модернізації системи вищої освіти України професійну підготовку майбутніх вихователів та майбутніх вчителів початкової школи прийнято розглядати 3 позицій компетентнісного підходу. В силу цього процес освіти спрямований на підготовку студента, який володіє професійною компетентністю, 
що й виступає головним iї результатом (В. Болотов, В. Сєріков, А. Маркова, В. Введенський). Професійна компетенція педагога - це наявність певного запасу знань, що дозволяють діяти самостійно при вирішенні педагогічних проблем; здатність застосовувати певні професійні педагогічні вміння під час вирішення нестандартних проблем; єдність теоретичної та практичної готовності до здійснення педагогічної діяльності; інтеграція досвіду, теоретичних знань і практичних умінь; наявність загальної культури особистості, а також значущих для педагога особистісних якостей.

3 метою розуміння сенсу понять «підготовка» та «професійна підготовка», звернемося до словників. Найбільш загальноприйнята розуміти під професійною підготовкою «систему організаційних і педагогічних заходів, що забезпечують формування у особистості професійної спрямованості (знань, навичок, умінь) i професійної готовності» (Шукин, 2008). У словнику С. Ожегова «підготовка» визначається як «запас знань, який отримуєхтось», а похідне дієслово «підготувати», що означає «зробити що-небудь, попередньо, для влаштування організації чого-небудь; навчити, дати необхідні знання для чогось; попереднім повідомленням розташувати до сприйняття чогось» (Ожегов, 2007). Під професійною підготовкою у педагогічному аспекті розуміють володіння системою спеціальних знань, умінь і навичок, які дозволяють виконувати роботу в певній галузі діяльності (Рапацевич, 2005). Ми погоджуємося з визначенням «підготовки», що відбите в словнику Д. Ушакова: «Підготовкою називають накопичення будь-ким достатнього запасу теоретичних знань, практичних навичок тощо, які необхідні для чого-небудь» (наприклад, рівень підготовки студентів) (Ушаков, 1947).

Узагальнюючи наукові позиції щодо підготовки педагогів до роботи 3 дітьми 3 особливими освітніми потребами, можна відзначити, що вчені представляють різні методологічні підходи. У числі цих підходів: особистіснодіяльнісний (В. Введенський, В. Краєвський, В. Шадриков та ін.), аксіологічний (I. Ісаєв, В. Сластьонін, С. Шиянов та ін.) та теоретичні основи компетентнісного (А. Маркова, О. Піскунова, Н. Радіонова та ін.); на наш погляд, саме у такому контексті забезпечується цілеспрямований професійний розвиток у педагогів таких компонентів готовності, як мотиваційно-ціннісного, операційнодіяльнісного та рефлексивно-оцінного. Ми погоджуємося з ідеями О. Піскунова та Н. Радіонова, які відзначають, що компетентність завжди проявляється в діяльності, при вирішенні вчителем професійних завдань в органічній єдності 3 цінностями людини, тобто за умови глибокої особистісної зацікавленості у даному виді діяльності. Авторами виділяються п'ять основних груп завдань, що відображають базову компетентність сучасного педагога: 1) бачити дитину (учня) в освітньому процесі; 2) будувати освітній процес, орієнтований на досягнення мети конкретної ступені освіти; 3) встановлювати взаємодію з іншими суб'єктами освітнього процесу, партнерами школи; 4) створювати та використовувати в педагогічних цілях освітнє середовище (простір школи); 5) проектувати і здійснювати професійну самоосвіта (Козырев, Радионова, Тряпицына, 2008). Дана позиція співпадає з думкою 3. Мовкебаївої й відповідає логіці нашого дослідження, оскільки узгоджується зі специфікою професійної діяльності педагога в умовах інклюзії. Від педагога, задіяного у роботуз дітьми 3 особливими освітніми потребами, потрібне знання психолого-педагогічних особливостей, вікових та індивідуальних особливостей розвитку дітей 3 особливими освітніми потребами, а також вміння виявляти дані особливості. При проектуванні інклюзивного освітнього процесу педагогічні працівники стикаються 3 необхідністю відбору оптимальних способів організації спільного 
навчання дітей 3 особливими освітніми потребами та 3 нормальним розвитком. По відношенню до дітей 3 особливими освітніми потребами це важливо для задоволення їх особливих освітніх потреб, а по відношенню до звичайних дітей для подолання негативізму у ставленні до однолітків 3 проблемами у здоров’ї. Відповідно, майбутній педагог повинен вміти створювати середовище, яке сприятиме розвитку і дітей 3 особливими освітніми потребами, i дітей 3 нормальним розвитком. Крім того, як зазначалося в рамках компетентнісного підходу, формування у педагога вмінь вирішувати професійні завдання нерозривно пов'язане із здійсненням власного професійного розвитку. 3 урахуванням викладеного вище, підготовку педагогів до роботи 3 дітьми 3 особливими освітніми потребами будемо розглядати як процес формування у них здатності вирішувати професійні завдання, що стосуються організації спільного навчання дітей 3 нормальним та порушеним розвитком. Структурний аналіз компонентів готовності показав неоднозначність поглядів дослідників.У структурі готовності педагога до інклюзивної освіти дітей науковці виділяють: професійну i психологічну готовність (С. Альохіна, М. Алексєєва), соціальну готовність (В. Хитрюк), які,на наш погляд, не в повній мірі відображають особистісні та діяльнісні сторони готовності. Доцільним, з нашої точки зору, є виділення компонентів, що відображають ціннісно-мотиваційну складову особистості педагога, до яких вчені відносять мотиваційний (С. Альохіна, М. Алексєєва, В. Хитрюк, Ю. Шуміловська), ціннісний (О. Самарцева) компоненти. На основі аналізу поглядів дослідників ми виділяємо особистісній компонент професійної готовності педагога. Виділено також компоненти готовності, що відбивають сформованість знань, умінь i навичок педагогів інклюзивної сфери: діяльнісний і когнітивний (Ю. Шуміловська), інформаційнокомпетентнісний та операційно-дієвий (В. Хитрюк). Узагальнюючи судження вчених ми виділяємо теоретичний компонент, що відображає теоретичні та методичні знання в сфері роботи з дітьми 3 особливими освітніми потребами. Погоджуючись 3 В. Хитрюк, в структурі готовності педагога виділено практичний (дієвий) компонент готовності як сукупність педагогічних умінь та навичок для реалізації інклюзивної освітнього процесу. Додаткові компоненти готовності, представлені дослідниками, відсвічують особистісні якості педагога: рефлексивний компонент (О. Кузьміна, I. Хафізулліна), емоційно-моральний компонент (В. Хитрюк), особистісна компетенція як здатність брати на себе відповідальність (С. Алексєєв). На відміну від авторів ці складові і компетенції ми розглядаємо в рамках особистісного компонента. Таким чином, серед пріоритетних компонентів вдосконалення професійної підготовки майбутніх вихователів дошкільних закладів освіти та майбутніх вчителів початкової школи до роботи 3 дітьми 3 особливими освітніми потребами виділяємо наступні: теоретичний (система знань та уявлень про особливості психофізичного розвитку та побудови на цій основі освітнього процесу), практичний (методи, форми та засоби реалізації професійно-педагогічних знань в роботі $з$ дітьми 3 особливими освітніми потребами, а також формування у майбутніх вихователів та вчителів відповідних професійних компетенцій) та особистісний (сукупність стійких мотивів, визнання кожної дитини вищою цінністю, суб'єктом освітньої діяльності, формування внутрішньої готовності до позитивного сприйняття «особливих дітей». На нашу думку, особлива увага повинна бути приділена теоретичному та практичному компонентам, так як освітня практика в українських дитячих садках та школах переконує, що велика частина учительства не готова до ефективної роботи 3 дітьми в умовах інклюзивної освіти. Саме в період проходження педагогічної практики студент має можливість віч-на-віч зустрітися $з$ реальним 
проблемами впровадження інклюзивної стратегії в масову систему освіти України; поспостерігати та попрацювати з дітьми різних категорій; вивчити їх особливості за допомогою комплексу спеціально підібраних методик; здійснити ранню діагностику інтересів та здібностей; виробити в собі почуття відповідальності, пов'язане 3 суспільною свідомістю; вирішувати проблеми у співпраці 3 іншими.На сьогодні потрібен новий освітній підхід до підготовки майбутнього вихователя та вчителя, заснований на компетентнісному підході, спрямований на вдосконалення теоретичного та практичного напрямів навчальних курсів, й педагогічної практики зокрема. Ми погоджуємося 3 думкою О. Жук, що «педагогічна підготовка студентів в університеті виступає ефективним засобом особистісного та професійного вдосконалення майбутніх фахівців» шляхом оволодіння ними психолого-педагогічними компетенціями (Жук, 2009). Так, отримавши практичний досвід перших професійних проб взаємодії з учасниками освітнього процесу у дитячому садку або початковій школі, студент приходить до осмислення необхідності отримання спеціальних знань та умінь. Адже дитячі садки та школи визначають замовлення по реалізації індивідуальних освітніх напрямів різного контингенту учнів: діти 3 особливими освітніми потребами, діти 3 девіантною поведінкою, обдаровані діти, соціально вразливі діти, діти-мігранти, діти сироти. Це психолого-педагогічне завдання студент може вирішити через освоєння навчальної дисципліни на вибір або варіативної частини модуля відповідної обов'язкової навчальної дисципліни. У зв'язку 3 цим, важливо включення у зміст ЗВО курсів відомостей 3 питань інклюзивної освіти, а також, на семінарських заняттях та в період педагогічної практики необхідно формувати професійні компетенції роботи 3 дітьми 3 особливими потребами.

Особистісний компонент підготовки фахівців включає толерантне ставлення до дітей 3 особливими освітніми потребами, адекватне сприйняття дітей з особливостями психофізичного розвитку, усвідомлення власних емоцій (емоційне прийняття дітей 3 різними типами «особливостей» (порушень) в розвитку) та вміння з ними вправлятися, розуміння особливостей таких дітей, їх сильні та слабкі сторони, вміння співпрацювати з батьками таких дітей. Разом 3 тим, важливо розуміти, що наявні проблеми ні в якому разі не повинні обмежувати можливості дитини у навчанні або спілкуванні 3 дітьми. Це допоможе майбутнім педагогам перебороти непевність у своїх можливостях вирішити поставлені перед ними задачі. Майбутньому фахівцю слід розуміти, що на даний час $\epsilon$ всі можливості для врахування особливостей різних категорій учнів при організації освітнього процесу, що дозволяє реалізовувати найбільш сприятливий варіант освіти та реабілітації дітей з обмеженими можливостями в рамках взаємодії їх з однолітками з нормальним розвитком.

\section{Висновки}

Інклюзія тягне за собою зміни і модифікації у змісті педагогічної підготовки, структурах та стратегіях, й передбачає багато варіантів вирішення виникаючих проблем. Теоретичний аналіз наукових праць дозволив нам визначити сутність та особливості підготовки майбутніх педагогів до роботи 3 дітьми 3 особливими освітніми потребами,яку ми розуміємо як багатогранну, особистісно-орієнтовану професійну характеристику, що відбиває знання танавички, а також ціннісні орієнтації, що дозволяють успішно здійснювати педагогічну діяльність у взаємодії із дітьми 3 типовим розвитком і дітьми 3 обмеженими можливостями здоров'я у просторі освітньої організації. У структурі готовності педагога до роботи 3 дітьми 3 особливими освітніми потребами нами 
виділені теоретичний, практичний та особистісній компоненти, завдяки яким можна досягти більш якісної підготовки кваліфікованих педагогів відповідного рівня. Це означає, що майбутні педагоги у В3О повинні тільки навчатися 3 метою засвоєння сучасних знань із загально-професійних та фахових дисциплін, виховання високоосвіченої та гармонійно розвиненої особистості, а й створення єдиної зони європейської освітипоширюючи ідеї здоров'язберігаючого навчання.

Перспектива подальших досліджень.Подальше дослідження заявленої проблеми, на нашу думку, має здійснюватися за такими напрямками:підготовка майбутніх вчителів початкових класів до роботи 3 дітьми з особливими освітніми потребами в умовах дистанційного навчання; інтеграція студентів 3 обмеженими можливостями здоров'я в інклюзивне освітнє середовище закладу вищоїосвіти та готовність викладачів до навчання студентів 3 обмеженими можливостями здоров’я.

\section{Література}

Черенько, Л. М. (2006). Рівень життя населення Украӥни: монографія. Київ: Консультант. 271. Гіn Ukrainian].

Демографічна та соціальна статистика. Населення та міграиія (1998-2019). Retrievedfrom: www.ukrstat.gov.ua/operativ/menu/menu_u/ds.htm [in Ukrainian].

Яковлева, Т.В. \& Баранов, А. А. (2009) Государственная политика в области охраны здоровья детей: проблемы и задачи. Вопросы современной педиатрии, 2, 6-10.Гin Ukrainian].

Закон України «Про освіту» (2017). Retrieved from: http://zakon4.rada.gov.ua/laws/show/1060-12.[in Ukrainian].

Шукин, А. Н. (2008). Лингводидактический энииклопедический словарь: более 2000 единии. Москва: Астрель: АСТ: Хранитель. 549. Гin Russian].

Ожегов, С. И. (2007). Словарь русского языка: ок. 53000 слов. Москва: Оникс; Издательство Мир и образование. 42. [in Russian].

Рапацевич, Е. С. (2005). Педагогика: Больщая современная эничиклопедия. Москва: «Соврем. слово». 437. Гin Russian].

Ушаков, Д. Н. (1947). Толковый словарь русского языка: в 4-х томах. Retrieved from: http://www.dict.t-mm.ru/ushakov. [in Russian].

Козырев, В. А., Радионова, Н. Ф.\& Тряпицына, А. П. (2008). Компетентностный подход в педагогическом образовании: коллективная монографія. Санкт-Петербург: Изд-во РГПУ им. А.И. Герцена. 295. 「in Russian].

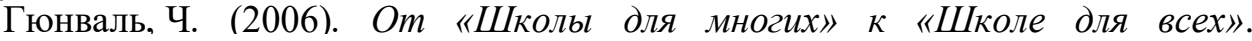
Дефектология. 2. 73 - 78. Гin Russian1.

Жук, О. Л. (2009). Педагогическая подготовка студентов: компетентностный подход. Минск: ВИВШ. 296. [in Belarus].

Udych, Z. (2017). Середовищний підхід у впровадженні інклюзивної освіти в середній загальноосвітній школі. Наукові записки Тернопільського начіонального педагогічного університету імені Володимира Гнатюка. Серія: педагогіка, 3. 127134. doi:http://dx.doi.org/10.25128/2415-3605.17.3.17 


\title{
FUTURE EDUCATORS AND TEACHERS OF INITIAL CLASSES TRAINING TO WORK WITH CHILDREN WITH SPECIAL EDUCATIONAL NEEDS
}

\author{
Natalia Agarkova, Associate Professor of the Department of primary, \\ preschool and vocational education, H. S. Skovoroda Kharkiv National \\ Pedagogical University, Kharkiv, Ukraine
}

\begin{abstract}
Raising and educating children with disabilities has always been a painful and difficult topic to discuss. However, at the present time, inclusive education has proved its relevance at the expense of the vision of the educational process from the point of view of enhancing the adaptive capacity of the main subiect of the education of the child. Such education can be a way of breaking down stereotypes in society, as it allows such children to be included in the school system and to ensure their full socialization. Inclusive education requires new programmers, new teaching AIDS and additional funding. Most importantly, changes in teacher training, namely, the readiness and ability of teachers teaches all children, without exception, regardless of characteristics and abilities, as well as development and limited opportunities. On the basis of a theoretical analysis of psychological, pedagogical, scientific and methodological literature, the concepts of "children with special educational needs», «inclusive education» are revealed, the concepts of «training» teachers are considered. The main idea of a scientific article is that the preparation of teachers for work in inclusive education is aimed at developing the professional competence of future teachers as the ability to solve professional problems in the field of inclusion. The main components of the readiness of future teachers to implement educational similarities with children with special educational needs are: theoretical, practical and personal, which include the system of knowledge and skills necessary to implement inclusive education; the formation of a complex of motives, goals and objectives of inclusive education; including personal factors (motivation to the development and implementation of inclusive education; reflection of a personal relationship to the process of this training), as well as a willingness to overcome difficulties and setbacks.

Kevwords: inclusive education; children with special educational needs; future teacher training; initial education; future teacher training; pre-school education.
\end{abstract}

\section{References}

Cherenko, L. M. (2006). Riven zhittya naselennya Ukraïni: monografiya. Kiïv: Konsultant. 271. [in Ukrainian].

Demografichna ta sotsialna statistika. Naselennya ta migratsiva (1998-2019). Retrievedfrom: www.ukrstat.gov.ua/operativ/menu/menu u/ds.htm [in Ukrainian].

Yakovleva, T. V. \& Baranov, A. A. (2009) Gosudarstvennaya politika v oblasti okhrany zdorovia detey: problemy i zadachi. Voprosy sovremennoy pediatrii. 2. 6-10. [in Ukrainian].
Zakon
Ukraïni «Pro
osvitu»
(2017).
Retrieved from:

http://zakon4.rada.gov.ua/laws/show/1060-12. [in Ukrainian].

Shchukin, A. N. (2008). Lingvodidakticheskiy entsiklopedicheskiy slovar: boleye 2000 edinits. Moskva: Astrel: AST: Khranitel. 549. [in Russian].

Ozhegov, S. I. (2007). Slovar russkogo yazyka: ok. 53000 slov. Moskva: Oniks; Izdatelstvo Mir i obrazovaniye. 42. [in Russian]. 
Rapatsevich, E. S. (2005). Pedagogika: Bolshaya sovremennaya entsiklopediya. Moskva: «Sovrem. slovo». 437. [in Russian].

Ushakov, D. N. (1947). Tolkovyy slovar russkogo yazyka: $v$ 4-kh tomakh. Retrieved from: http://www.dict.t-mm.ru/ushakov. [in Russian].

Kozyrev, V. A., $\quad$ Radionova, N. F. \& $\quad$ Tryapitsyna, A. P. (2008). Kompetentnostnyy podkhod $v$ pedagogicheskom obrazovanii: kollektivnaya monografiva. Sankt-Peterburg: Izd-vo RGPU im. A. I. Gertsena. 295. [in Russian].

Gyunval, Ch. (2006). Ot «Shkoly dlya mnogikh» $k$ «Shkole dlya vsekh». Defektologiva. 2.73 - 78. [in Russian].

Zhuk O. L. (2009). Pedagogicheskaya podgotovka studentov: kompetentnostnyy podkhod. Minsk: VIVSh. 296. [in Belarus].

Udych, Z. (2017). Seredovishchniy pidkhid u vprovadzhenni inklyuzivnoï osviti v seredniv zagalnoosvitniv shkoli. Naukovi zapiski Ternopilskogo natsionalnogo pedagogichnogo universitetu imeni Volodimira Gnatvuka. Seriva: pedagogika. 3. 127134. doi:http://dx.doi.org/10.25128/2415-3605.17.3.17 [in Ukrainian]. 
